\title{
Production and quality of melon hybrid Mandacaru irrigated with different levels of salinity
}

\author{
Damiana Cleuma de Medeiros; José Francismar de Medeiros; Francisco Aécio de L Pereira; Sonally \\ Cristina de M Silva; Maria das Graças Amâncio \\ UFERSA-Depto. Ciências Ambientais, C. Postal 137, 59625-900 Mossoró-RN; damianacm@hotmail.com; jfmedir@cnpq.br; \\ aecioagro@hotmail.com; sonally_cristina@hotmail.com; mdga_21@hotmail.com
}

\begin{abstract}
Among the problems faced by the melon crop in the state of Rio Grande do Norte, northeastern Brazil, the effect of water and soil salinity is considered one of the key factors to limit fruit production and quality. The aim of this work was to study the effects of using irrigation waters with different salinity levels on yield and quality of fruits of the yellow melon hybrid Mandacaru. A randomized complete block design was used with five treatments (irrigation water salt concentrations: $0.54,1.48,2.02,3.03,3.9 \mathrm{dS} \mathrm{m}^{-1}$ ) and four replications. The effects of these concentrations were evaluated through, number of marketable fruits per plant, marketable and total fruit yield, average marketable fruit mass, soluble solids content and pulp firmness. Increment in water salinity level negatively influenced crop yield. The $3.9 \mathrm{dS} \mathrm{m}^{-1}$ salinity level caused yield losses of $20.31 \%$, due to the reduction of fruit number per plant. The highest soluble solid content and the highest pulp firmness values were estimated to occur at salinity levels 2.09 and $3.5 \mathrm{dS} \mathrm{m}^{-1}$, respectively.
\end{abstract}

Keywords: Cucumis melo L., electric conductivity, yield.

\section{RESUMO}

Produção e qualidade de melão híbrido Mandacaru irrigado com diferentes níveis de salinidade

Dentre os problemas enfrentados pela cultura do melão no estado do Rio Grande do Norte, a salinidade da água e do solo é considerada um dos principais fatores que limitam a produção e a qualidade dos frutos. O objetivo do trabalho foi estudar os efeitos de aplicação de águas de irrigação com diferentes níveis de salinidade na produção e qualidade do melão Amarelo híbrido Mandacaru. O delineamento utilizado foi de blocos completos casualizados com quatro repetições. Os tratamentos constaram de concentrações de sais na água de irrigação $\left(0,54 ; 1,48 ; 2,02 ; 3,03 ; 3,9 \mathrm{dS} \mathrm{m}^{-1}\right)$. As características avaliadas de produção e qualidade foram: produtividade total e comercial, número de frutos comerciais por planta, massa média de frutos comerciais, sólidos solúveis (SS) e firmeza de polpa. O incremento do nível de salinidade da água influenciou negativamente o rendimento da cultura, tendo o nível de salinidade de $3,9 \mathrm{dS} \mathrm{m}^{-1}$ proporcionando perdas de produtividade na ordem de $20,31 \%$, motivada pela redução do número de frutos por planta. Os maiores valores de firmeza de polpa e SS ocorreram nos níveis de salinidade 2,09 e 3,5 $\mathrm{dS} \mathrm{m}^{-1}$, respectivamente.

Palavras-chave: Cucumis melo L., condutividade elétrica, rendimento.

(Recebido para publicação em 20 de abril de 2010; aceito em 18 de julho de 2011)

(Received on April 20, 2010; accepted on July 18, 2011)

$\mathrm{T}$ he fruit vegetables are grown in all regions of Brazil. In Northeastern Brazil, soil and climatic conditions favor the cultivation of these vegetables contributing to the proper development and growth of plants and fruits. Among these vegetables are plants of the Cucurbitaceae family, especially the melon and the watermelon. In Brazil, in $2008,534,124 \mathrm{t}$ of melons were produced in 21,350 ha of harvested area, and the northeast region accounted for $86 \%$ of the harvested area (IBGE, 2009). Regarding the State of Rio Grande do Norte, the melon crop occupies an area of 12,000 hectares in the axes AssuMossoró-Baraúnas, generating 28,000 direct jobs and 52,000 indirect jobs (SET, 2008).
Irrigated agriculture relies on the quantity and quality of water. Among the characteristics that determine the quality of water for irrigation, the concentration of soluble salts or salinity is a limiting factor to the development of some crops (Bernardo, 1996). Efficient use of water is becoming increasingly important due to the scarcity of water resources in the region and the high cost of energy, which makes increasingly necessary the adoption of appropriate methodologies for the rational management of water use (Lima, 2001).

In thes state of Rio Grande do Norte, low salinity water is available at a high cost and limited volume, and water from shallow wells is available at a lower cost and higher use potential, but, it can present high level of salinity and, in some cases, it can reduce the crop yield. The melon production, in this State, is concentrated in the agriculture pole Mossoró-Açu and in the Chapada do Apodi, covering the semi-arid region close to the coast region, where soils and irrigation water with high salinity levels are predominant. In these areas, the intense evaporation, the deficient drainage and the use of fertilizers increase the occurrence of high salinity, reducing the crop yield (Medeiros, 2001).

The effects of salts on plants may be noted based on the difficulty of absorption of saline water, by the interference of salts in the physiological processes, or even toxicity, similar 
to those of excessive fertilization (Queiroga et al., 2006). Among the problems faced by the crop, the salinity of water and soil are limiting factors for a good yield and fruit quality. The melon crop presents a wide variation in the level of salt tolerance, which can depend on cultivars, environmental conditions and management (Francois \& Maas, 1993). The salinity tolerance of melon is not well related to the first and the last stages of development. Species and cultivars exhibit variable tolerance to salinity, which makes the necessity and the management of the leaching of salts in the soil specific for each crop and cultivar. There is a necessity to develop melon cultivars with tolerance to salts, due to the increasing salinity in the soil, since plants do not generally develop tolerance to salts, unless they grow in saline conditions (Sivitrepe et al., 2003). Barros (2002) found that the soil salinity is directly related to the irrigation water, increasing since the beginning of planting and decreasing at the end of season in melon irrigated with water at different levels of salinity in the conditions of Mossoró, in Rio Grande do Norte State. Soil salinity is one of the important factors that affect crop yields.

In the case of irrigated areas in arid and semi-arid regions, salinity is a serious problem and may limit production at uneconomic levels. The aim of this work was to study the effects of application of irrigation waters with different salinity levels on yield and quality of yellow melon hybrid 'Mandacaru'.

\section{MATERIAL AND METHODS}

The experiment was carried out from November 2008 to January 2009, in Pedra Preta farm, Mossoró, Rio Grande do Norte state. This farm belongs to the Coopy Frutas group (4³9'39'S, $37^{\circ} 23$ ' 13 "W). The local climatic classification according to Koeppen is BSwh', the climatic conditions during the experimental period were: average temperature $27.9^{\circ} \mathrm{C}$, precipitation 15 $\mathrm{mm}$, average air moisture $63.4 \%$ and ETo $6.60 \mathrm{~mm}$ (PENMAN-MONTEITH FAO) according to the meteorological station of Pau Branco in Mossoró. This meteorological station was localized 15 $\mathrm{km}$ from the experimental area.

The soil of the experimental area is Argissolo Vermelho-Amarelo (Embrapa, 1999). Chemical analysis were carried out at the laboratories of the Universidade Federal Rural do Semi-Árido and Federal University of Campina Grande. The results were: $\mathrm{pH}=8.0$; organic matter content $=3.0 \mathrm{~g}$ $\mathrm{kg}^{-1} ; \mathrm{P}=10.0 \mathrm{mg} ; \mathrm{K}^{+}=1.1 \mathrm{mmol}_{\mathrm{c}} \mathrm{dm}^{-3}$; $\mathrm{Ca}^{2+}=9.0 \mathrm{mmol}_{\mathrm{c}} \mathrm{dm}^{-3} ; \mathrm{Mg}^{2+}=4.0 \mathrm{mmol}$ $\mathrm{dm}^{-3} ; \mathrm{H}+\mathrm{Al}^{3+}=18.0 \mathrm{mmol} \mathrm{dm}^{-3} ; \mathrm{CTC}=$ $32.1 \mathrm{mmol}_{\mathrm{c}} \mathrm{dm}^{-3}$.

The soil was tilled through one plowing and one harrowing operation to clean the area and then a subsoiling operation.

The basic fertilization was done with $420 \mathrm{~kg} \mathrm{ha}^{-1}$ of the formula 6-2412. The topdressing was carried out through fertigation according to the recommendation of Crisostomo et al. (2002). The doses applied during the crop season were: $81 \mathrm{~kg}$ of $\mathrm{N}, 93 \mathrm{~kg}$ of $\mathrm{P}_{2} \mathrm{O}_{5}$ and $188 \mathrm{~kg} \mathrm{ha}^{-1}$ of $\mathrm{K}_{2} \mathrm{O}$ plus micronutrients. A complementary fertilization was carried out through the application of fertilizers with micronutrients according to the plant stage and the plant nutritional requirements and, also, a foliar supplementation of micronutrients was carried out with $6.83 \mathrm{~L} \mathrm{ha}^{-1}$ of $\mathrm{CaB}_{2}$ ( $2 \%$ of $\mathrm{B}$ and $8 \%$ of $\mathrm{Ca}$ ) and $1.09 \mathrm{~L} \mathrm{ha}^{-1}$ Megafol (nitrogen (N) 11\%; potassium oxide $\left(\mathrm{K}_{2} \mathrm{O}\right) 1 \%$; organic carbon $(\mathrm{C})$ $14.5 \%$.

Seeding was done onto trays of 200 cells with commercial substrate. Transplanting was carried out when the second definite leaf was totally expanded, with one plant per pit. The plant line was kept covered with polyethylene film "mulching" throughout the season and plants were protected with blanket (TNT) until the beginning of flowering. The spacing used in the experiment was $2 \times 0.4 \mathrm{~m}$, and the plot consisted of four rows of $6 \mathrm{~m}$, the two central plots being considered as useful ones. For the treatments, water of low salinity and water with high salinity were mixed, originating the following salinities expressed in electrical conductivities $\left(0.54,1.48,2.02,3.03,3.9 \mathrm{dS} \mathrm{m}^{-1}\right)$. The treatments were arranged in randomized complete blocks with four replications.

The cultivar was the hybrid Mandacaru (Yellow Melon), characterized by round fruits, furrowed bark, medium size ( 1.5 to $2.3 \mathrm{~kg}$ ), thick and firm pulp, excellent post-harvest and yellow gold coloration. The plant has medium cycle length, high vigor and high potential for export; the cultivar is one of the most cultivated by the local farmers.

Irrigation of plots was made by drip, spaced at $40 \mathrm{~cm}$ with a flow rate of 1.35 $\mathrm{L} \mathrm{h}^{-1}$, and application of a total $324 \mathrm{~mm}$. The water, after mixed, was applied by an independent system with a lateral line per row. One daily irrigation was carried out until 30 days after transplanting and, then, two daily irrigations were carried out, keeping the soil water content at the field capacity.

Weeding and pulverization against whitefly (Bemisia tabaci), Liriomyza huidobrensis, fruit borer (Diaphania nitidalis), powdery mildew (Uncinula necator and the mildew (Downy mildew) were carried out.

The melon harvest occurred in December 2008 extending to January 2009.

The production characteristics evaluated were: yield of marketable fruits (PFC) (dividing the sum of the masses of fruit ready for export by the number of plants harvested in the useful portion and then multiplied by the number of plants in $1 \mathrm{ha}$ ), total fruit yield (PFT) (dividing the sum of the masses of fruit by total number of plants harvested in the useful portion and then multiplied by the number of plants in an hectar), number of marketable fruits (NFC) (total number of fruit suitable for export per plot divided by the number of useful plants harvested), the mean weight of marketable fruits per plant (MMFC) (total mass of fruit suitable for export divided by the number of fruits per plant harvested in the useful plot). Quality characteristics were also evaluated: soluble solids (SS) of marketable fruits through a digital refractometer with automatic temperature correction, the results being expressed in percentage; pulp firmness determined in fruits cut longitudinally, 
in which readings with a penetrometer Pluger of $8 \mathrm{~mm}$ diameter was carried out, the results being obtained in pound (lb), converted to Newton $(\mathrm{N})$, using the conversion factor 4.45 . The data were subjected to analysis of variance and regression using the statistical analysis program SAEG, v. 9.0 (Ribeiro Júnior, 1999).

\section{RESULTS AND DISCUSSION}

A significant regression model was observed for the variables total number of marketable fruits, total and marketable productivity, pulp firmness and total soluble solids. The linear and quadratic models can explain the variables production (Table 1) and quality (Figures 1 and 2) in melon, except for the average mass of marketable fruits which did not fit any model. The increase of the concentration of salts influenced negatively the total number of fruits per plant, yield of total and marketable fruits.

For the number of marketable fruits per plant (Table 1) from the salinity corresponding to the value of $0.54 \mathrm{dS} \mathrm{m}^{-1}$ on, a linear reduction was observed with the increase of salinity for the number of fruits, decreasing from 1.59 to 1.29 fruits from the lowest to the highest salinity, corresponding to a decrease of $18.86 \%$. In relation to relative values, a linear loss of fruits of $23.4 \%$ of the level $3.9 \mathrm{dS} \mathrm{m}^{-1}$ in comparison to the level $0.54 \mathrm{dS} \mathrm{m}^{-1}$ was observed. These data are in agreement with Silva et al. (2005) who worked on different salinity levels (1.2 $\mathrm{dS} \mathrm{m}^{-1}, 2.5 \mathrm{dS} \mathrm{m}^{-1}$ and $4.4 \mathrm{dS} \mathrm{m}^{-1}$ ), and observed similar results. The same way, Mendlinger (1994), growing Gália melon, in four different levels of salinity of irrigation water, showed a reduction in the components of yield with the increase of the levels of the salinity of the water. The results are in accordance with those ones reported by Costa (1999), showing the same reduction in the number of commercial fruits for Gold Mine cultivar using two different levels of salinity in the irrigation water (0.55 and $2.65 \mathrm{dS} \mathrm{m}^{-1}$ ).

The average mass of the marketable fruits in total and relative values was not influenced by the difference of salinity, observed in Table 1, showing an average value of $2.95 \mathrm{~kg}$, pointing out an adequate value for this feature for the market of 'Yellow' melon. These results differ from the ones reported by Medeiros et al. (2008), evaluating the effect of the frequency of the water in different levels of salinity (1.1, 2.5 and $4.5 \mathrm{dS} \mathrm{m}^{-1}$ ) and two different hybrids of melon (Trusty and Orange Flesh), observing a decrease of average mass of the fruits because of the salty water. The difference of behavior related to the effect of salinity on the average mass of the fruits reported on the studies can be explained by the different behavior among the cultivars in response to salinity. According to Alencar et al. (2003) and Dias et al (2006), the decrease of the yield of melon, in response to salinity, is due to the decrease of the number with the average mass of the fruits or simply to the decrease of the number or to the decrease of the average mass.

A similar behavior was noticed for the total and marketable fruit productivity in response to the salinity of the irrigation water. A linear decrease was observed, of $20.31 \%$ and $21.97 \%$ for total and marketable yield, respectively, in the level $3.9 \mathrm{dS} \mathrm{m}^{-1}$ in relation to $0.54 \mathrm{dS} \mathrm{m}^{-1}$ (Table 1). For relative values, a linear decrease was noticed, with a reduction of $20.27 \%$ and $21.81 \%$ for total and marketable yield, respectively, in 3.9 $\mathrm{dS} \mathrm{m}^{-1}$ level in relation to $0.54 \mathrm{dS} \mathrm{m}^{-1}$. According to the results, the main cause for the reduction of the productivity of the fruits is the low number of fruits per plant, when the levels of salts in the water are high, since the reduction of the mass is very little, not affecting the productivity. The low number of marketable fruits per plant occurs because of some influence of the salinity in the external appearance of the fruit. In this case, the fruit is not considered a marketable fruit. Similar results were reported by Brito (1997) working on the level of salinity of the irrigation water of $1.50 \mathrm{dS} \mathrm{m}^{-1}, 3.00 \mathrm{dS} \mathrm{m}^{-1}$ and $4.50 \mathrm{dS} \mathrm{m}^{-1}$, showing that a salinity level higher than $4.50 \mathrm{dS} \mathrm{m}^{-1}$ lead to a significant decrease in the melon yield. Similar results were also observed by Costa (1999), studying Gold Mine cultivar, testing two different levels of salinity in the irrigation water $\left(0.55\right.$ and $\left.2.65 \mathrm{dS} \mathrm{m}^{-1}\right)$, when some losses in the productivity of $10 \%$ and $27.5 \%$ of the cultivar were observed, in two different experiments respectively, using water of $2.65 \mathrm{dS}$ $\mathrm{m}^{-1}$, in comparison to the productivity obtained with water of $0.60 \mathrm{dS} \mathrm{m} \mathrm{m}^{-1}$.

A significant effect was observed for SS and pulp firmness in relation to salinity. In Figure 1, a decrease in the SS content with an increase of salinity was observed in the beginning, afterwards a decrease and after that an increase of SS values. SS values in melon are very desirable and widely accepted because this is a very important parameter in many countries, including Brazil. The definition of the minimum best harvesting stage, since the standards are fitted, should be made based on

Table 1. Number of marketable fruits per plant depending on different levels of salinity (valores absolutos e relativos do número de frutos comerciais por planta em função de diferentes níveis de salinidade), average mass of marketable melon fruits irrigated with different levels of salinity (massa média de frutos comerciais em função de diferentes níveis de salinidade), total and marketable fruits yield irrigated with different levels of salinity (produtividade de frutos comerciais e totais em função de diferentes níveis de salinidade). Mossoró, UFERSA, 2009.

\begin{tabular}{llll}
\hline Yield characteristics & Absolute values & Relative values (\%) & $\mathbf{R}^{\mathbf{2}}$ \\
\hline Number of marketable fruits/plant & $\mathrm{Y}=-0.09 \mathrm{x}+1.64$ & $\mathrm{Y}=-6.0 \mathrm{x} 104.0$ & 0.87 \\
Average commercial fruits' mass $(\mathrm{kg})$ & $\mathrm{Y}=0.028 \mathrm{x}+2.944$ & $\mathrm{Y}=-0.9 \mathrm{x}+104.7$ & 0.59 \\
Yield of marketable fruits $\left(\mathrm{t} \mathrm{ha}^{-1}\right)$ & $\mathrm{Y}=-2.89 \mathrm{x}+49.36$ & $\mathrm{Y}=-6.2 \mathrm{x}+106.1$ & 0.86 \\
Yield of total fruits $\left(\mathrm{t} \mathrm{ha}^{-1}\right)$ & $\mathrm{Y}=-2.51 \mathrm{x}+40.18$ & $\mathrm{Y}=-6.8 \mathrm{x}+108.4$ & 0.73 \\
\hline
\end{tabular}




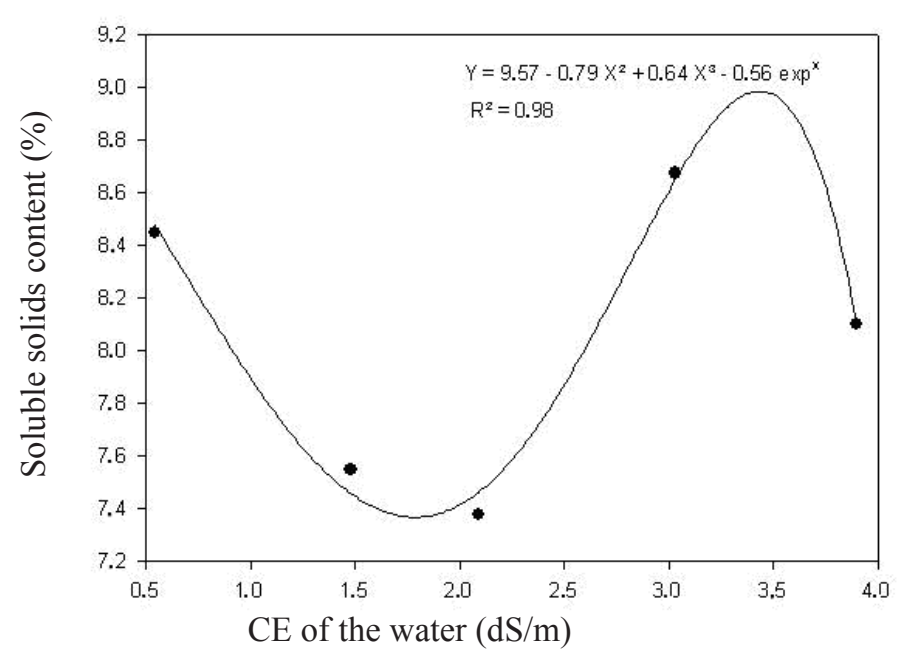

Figure 1. Soluble solids content of melon fruits irrigated with different levels of salinity (sólidos solúveis totais de melão em função de diferentes níveis de salinidade). Mossoró, UFERSA, 2009.

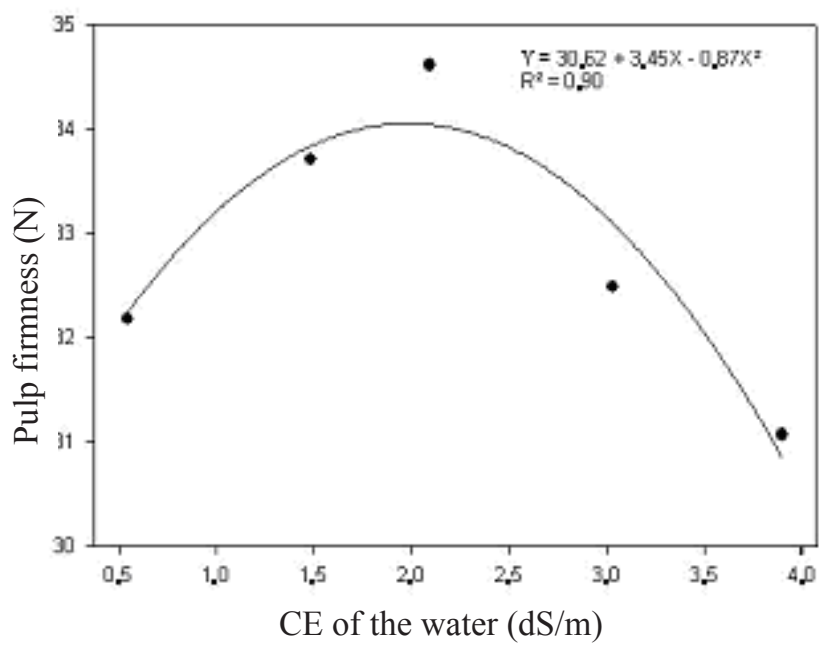

Figure 2. Pulp firmness of melon fruits irrigated with different levels of salinity (firmeza de polpa de melão em função de diferentes níveis de salinidade). Mossoró, UFERSA, 2009.

the time necessary to the product to reach its market, knowing that the fruit can become softer, the color of skin can change but no increase of soluble solids occur after harvest. The results for these traits are similar to the results obtained by Barros (1998), who aimed at evaluating the quality and durability of the melon, submitted to nine different combinations of water with electric conductivity from 1 to $5 \mathrm{dS} \mathrm{m}^{-1}$ and presented higher SS values than the ones in fruits irrigated with non-salty water. On the other hand, Porto Filho et al., (2009) pointed no interference of the increase of salinity in soluble solids in yellow melon; these results are in agreement with the ones observed by Barros (2002) and Dias et al., (2005). However, Porto Filho et al., (2009) pointed out that the studied melon could have been not mature enough, because it is known that the soluble solid contents in melon increase as the fruit gets mature (Menezes, 1996).

In Figure 2, an increase in pulp firmness of the fruit for salinity levels varying from $0.54 \mathrm{dS} \mathrm{m}^{-1}$ up to about $2.09 \mathrm{dS} \mathrm{m}^{-1}$ is observed, value where the highest firmness was reported (34.61 $\mathrm{N})$, followed by a decrease of the pulp firmness for salinity 3.03 and $3.9 \mathrm{dS} \mathrm{m}^{-1}$. This information can be useful for future experiments to determine the best salt concentration in order to obtain better quality fruits. Pulp firmness is a result of the class and quality of the fruits' pectic components, such as protopectin, which is located in the middle lamella of the adjacent cells and in the primary wall. Because of its partial insolubility, protopectin keeps the fruit consistence, turning into a soluble compost as the fruit gets mature, softening the pulp (Menezes et al. 2000). Amor et al. (1999) also pointed out that in 'Gália' melon, which the component of quality is the pulp firmness, the salinity level made a great difference. The results showed in this work are not in agreement with the ones reported by Barros (2002), which showed no increase of pulp firmness with the increase of salinity.

The increase of the salinity level in the water influenced negatively the yield and the level of salinity of $3.9 \mathrm{dS} \mathrm{m}^{-1}$ caused losses of productivity of about $20.31 \%$, motivated by the reduction of the number of the fruits per plant. The highest values for pulp firmness and SS are reported in salinity levels of 2.09 and $3.5 \mathrm{dS} \mathrm{m}^{-1}$, respectively.

\section{AKNOWLEDGEMENT}

To CNPq for financial support and Post Doctoral scholarship; To the Company Clause Brasil Comércio de Sementes Ltda for the seeds donation; To the Company CopyFrutas for support in the experiments execution, giving the experimental area; To FINEP/ FAPERN/UFERSA/EMPARN/UFRNCTARN for support in the research realization. To CAPES/PROCAD-NF for the financial support.

\section{REFERENCES}

\section{ALENCAR RD; PORTO FILHO FQ; MEDEIROS} JF; HOLANDA JF; PORTO VCN; FERREIRA NETO M. 2003. Crescimento de cultivares de melão Amarelo irrigados com águas salinas. Revista Brasileira de Engenharia Agrícola e Ambiental 7: 221-223.

AMOR FM; MARTINEZ V; CERDÁ A. 1999. Sality duration and concentration affect fruit yield and quality, and growth and mineral composition of melon plants grown in perlite. HortScience 34:1234-1237.

BARROS AD. 2002. Manejo da irrigação por gotejamento, com diferentes níveis 
de salinidade da água, na cultura do melão. Botucatu: UNESP-FCA, 124p (Tese doutorado).

BARROS AD. 1998. Germinação, vigor e desenvolvimento do meloeiro (Cucumis melo, L.) sob diferentes níveis de salinidade da água de irrigação. Campina Grande: UFPB. 78p (Dissertação mestrado).

BERNARDO S. 1996. Manual de irrigação. 6.ed. Viçosa: UFV. 488p.

BRITO GNS. 1997. Produtividade do melão irrigado por gotejamento com água de diferentes níveis salinos. Fortaleza: UFC. 87p. (Dissertação mestrado).

COSTA MC. 1999. Efeito de diferentes lâmina de água com dois níveis de salinidade na cultura do meloeiro. Botucatu: UNESP. 115p. (Tese doutorado).

CRISÓSTOMO LAAA; RAIJ B; FARIA CMB; SILVA DJ; FERNANDES FAM; SANTOS FJS; CRISÓSTOMO JR; FREITAS JAD; HOLANDA JS; CARDOSO JW; COSTAND. 2002. Adubação, irrigação, híbridos e práticas culturais para o meloeiro no Nordeste. Fortaleza: Embrapa Agroindústria Tropical. 21p. (Circular Técnica 14).

DIAS NS; DUARTE SN; MEDEIROS JF; VÁSQUEZ MN. 2005. Calidad post-cosecha de frutos de melón producidos sobre diferentes niveles de salinidad del suelo y manejos de la fertirrigación invernadeiro. Ingeniería De Lagua, 12: 117-123.

DIAS NS; DUARTE SN; MEDEIROS JF; TELES FILHO JF. 2006. Salinidade e manejo da fertirrigação em ambiente protegido. II: Efeito sobre o rendimento do meloeiro. Irriga 11:
376-383.

EMBRAPA - Centro Nacional de Pesquisa de Solos (Rio de Janeiro, RJ). 1999. Sistema Brasileiro de Classificação de Solos - Brasília: EMBRAPA, , 412f.

FRANCOIS LE; MAAS EV. 1993. Crop response and management on salt-affected soils. In: PESSARAKALI M. (ed). Handbook of plant and crop stress. New York: Marcel Dekker. p.149-181.

IBGE. INSTITUTO BRASILEIRO DE GEOGRAFIA E ESTATÍSTICA. 2009. Lavoura temporária. Disponível em http:// www.ibge.gov.br/estadosat/temas.php?sigla= rn\&tema=lavouratemporaria2007. Acessado em: 24 de março de 2009.

LIMA AA. 2001. Absorção e eficiência de utilização de nutrientes por híbridos de melão (Cucumis melo L.). Fortaleza: UFC. 60p. (Dissertação mestrado).

MEDEIROS JF. 2001. Salinização em áreas irrigadas: manejo e controle. In: FOLEGATTI MV; CASARINI E; BLANCO FF; BRASIL RPC; RESENDE RS. Fertirrigação: flores, frutas e hortaliças. Guaíba: Agropecuária. 2: 201-240.

MEDEIROS JF; DIAS NS; BARROS AD. 2008. Manejo da irrigação e tolerância do meloeiro a salinidade da água de irrigação. Revista Brasileira Ciências Agrárias 3: 242-247.

MENDLINGER S. 1994. Effect of increasing plant density and salinity on yield and fruit quality in muskmelon. Scientia Horticulturae 57: 41-49.

MENEZES JB. 1996. Qualidade pós-colheita de melão tipo Gália durante a maturação e o armazenamento. Lavras: UFLA. 157p. (Tese doutorado).

MENEZES JB; FILGUEIRAS HAC; ALVES RE; MAIA CE; ANDRADE GG; ALMEIDA JHS; VIANA FM. 2000. Características do melão para exportação. In: ALVES RE. Manual de melão para exportação: procedimento de colheita e pós-colheita. Fortaleza: Embrapa Agroindústria Tropical. 44p.

PORTO FILHO FQ; MEDEIROS JF; SENHOR RF; MORAIS PLD; MENEZES JB. 2009. Qualidade de frutos do melão amarelo irrigado com água de diferentes níveis de salinidade. Revista Caatinga 22: 93-198.

QUEIROGA RCF; ANDRADE NETO RC; NUNES GHS; MEDEIROS JF; ARAÚJO WBM. 2006. Germinação e crescimento inicial de híbridos de meloeiro em função da salinidade. Horticultura Brasileira 24: 315-319.

RIBEIRO JÚNIOR JI. 1999. Sistema para Análises Estatísticas. Viçosa: UFV, Imprensa Universitária, 141p.

SET. 2008. Turismo lidera investimentos no RN (Tribuna do Norte - 14/11/2005). Disponível em: http://www.set.rn.gov.br/set/ noticias/arquivos/not/14nov2005\%20-\%20 Turismo $\% 201$ idera $\% 20$ investimentos $\% 20$ no\%20RN.htm. Acesso em: 14 de março 2009.

SILVA HR; COSTA ND; CARRIJO OA. 2005. Exigências de clima e solo e época de plantio. In: SILVA HR; COSTA ND. (eds). Melão: produção, aspectos técnicos. Brasília: Embrapa. p. 23-28.

SIVITREPE N; SIVITREPE HO; ERIS A. 2003. The effect of $\mathrm{NaCl}$ priming on salt tolerance in melon seedling grown under saline conditions. Scientiae Horticulturae 97: 229-237. 